\section{When is a Christmas party not a Christmas party? When it's in Downing Street}

\author{
Andy Cowper editor
}

Christmas is a time for traditions, and one of our great British traditions is bad jokes. Whether it's the groan-inducing fare of pantomime scripts, or the hackneyed humour found inside Christmas crackers, "so bad it's good" humour is a key part of this season's rituals.

In this spirit of tradition, I offer readers of The BMJ not only my best wishes for the festive season, but the bad joke that titles this column.

It feels quite meta to be making a bad joke about a bad joke. And for 10 Downing Street to have been allegedly holding a party on 18 December 2020 that was in breach of coronavirus restrictions then in place, as the Downing Street Twitter account confirmed at that time, was a profoundly unfunny gag. London was at that time in tier three restrictions, the legislation for which can be read here. ${ }^{1-3}$

There are now reports that the Downing Street Christmas party held on 18 December 2020, first revealed by the Daily Mirror last week, was well known throughout Downing Street, and in particular by the prime minister's then spokesperson Allegra Stratton. ${ }^{4}$ Footage leaked to ITV News, dating from 20 December 2020, shows Stratton laughing and joking with Downing Street colleagues about how they would handle media questions about the party. ${ }^{5}$

BBC political editor Laura Kuenssberg tweeted that party attendees told her they'd been invited to attend by Downing Street political staff, as well as by civil servants. $^{6}$

\section{Demonstrable untruths}

Downing Street spokespeople, cabinet ministers, Conservative MPs, and the prime minister have spent the past week since the Mirror story appeared denying that there was a party in Downing Street, while also claiming that, if there had been a party, all rules were followed. Both of these assertions are now called into question by the ITV footage of Stratton.

\section{Strattexit}

Stratton, a former journalist, has just accepted the inevitable, and resigned in a tearful statement. ${ }^{78}$

Her statement of apology says that "my remarks seemed to make light of rules, rules that people were doing everything to obey." 9 This use of the word "seemed" is a telling way of delivering a "non-apology" apology: a classic hallmark of the (wrongly) intellectually smug.

Stratton was merely echoing the approach of Boris Johnson, her ex-boss, who at prime minister's questions said "I apologise unreservedly for the offence this has caused, up and down the country, and for the impression it has given." ${ }^{10}$ Another clear "non-apology" apology.

Yet Johnson continued to claim that this party-indeed, these parties-did not happen. Indeed, at last night's Downing Street briefing, the prime minister stated, “as far as I'm aware, and to the best of my knowledge, we followed the rules throughout ... even on 18 December last year." He also went on to state "you've got to act to protect public health when you've got clear evidence." Governing by irony is evidently Johnson's thing.

The prime minister has now been forced into getting cabinet secretary Simon Case to launch an inquiry into a number of events alleged to have taken place last year. ${ }^{11}$

\section{Why does this matter?}

This is quite the opposite of a "Westminster bubble" story. It has national importance for the NHS and the medical profession. This is because the growth of covid-19 infections, clearly driven by the more infectious Omicron variant, has driven us into the Plan $B$ restrictions announced by the prime minister Boris Johnson at the Downing Street briefing last night. $^{12}$

Will people be inclined to follow these restrictions and rules set by a government that consistently flouts them? There is cause for concern. We have evidence published in The Lancet that the revelation of and incredible excuses for Dominic Cummings's own northern flit for "childcare" and Barnards Castle "eye test" day trip while he was still in post as an advisor at No 10 had a measurable negative effect on public compliance with covid-19 regulations. ${ }^{13} 14$ This finding was corroborated by another study from the London School of Economics. ${ }^{15}$

Doctors have been at the front line of covid-19, putting their own personal safety on the line, and many didn't survive. ${ }^{16}$

Considering these risks and sacrifices made by the medical and caring professions, and those made by the vast majority of the country who complied with the covid-19 rules, Downing Street's alleged flouting of its own covid-19 laws and rules is more than a bad joke: it is obscene. The government's apparent attempts to cover up and lie about what appears to have been an open secret internally adds insulting our intelligence to injury.

Competing interests: None declared.

Commissioning and peer review: Commissioned; not externally peer reviewed.

Cabinet Office. Guidance for the Christmas period. 2020. https://www.gov.uk/guidance/guidance-for-the-christmas-period 


\section{OPINION}

2 GOV.UK. Twitter 2020. https://twitter.com/GOVUK/status/1339594604522270721

3 UK Government. The Health Protection (Coronavirus, Restrictions) (All Tiers) (England) Regulations 2020. 2020. https://www.legislation.gov.uk/uksi/2020/1374/schedule/3/made

4 Crerar P. Families' fury at Boris Johnson's 'sickening' boozy lockdown Christmas parties scandal. 2021. https://www.mirror.co.uk/news/politics/families-fury-boris-johnsons-sickening-25594927

5 ITV News. Downing Street staff shown joking in leaked recording about Christmas party they later denied. 2021. https://www.itv.com/news/2021-12-07/no-10-staff-joke-in-leaked-recordingabout-christmas-party-they-later-denied

6 Kuenssberg L. Twitter. https://twitter.com/bbclaurak/status/1468585042607759362

7 Waterson J. How Allegra Stratton's struggles kept press briefing project off air. 2021.

https://www.theguardian.com/politics/2021/dec/08/how-allegra-strattons-struggles-kept-pressbriefing-project-off-air

$8 \quad$ BBC News. Allegra Stratton resigns over No 10 Christmas party video. 2021 https://www.bbc.co.uk/news/uk-politics-59584736

9 Swinford S. Twitter. https://twitter.com/steven_swinford/status/1468606233162797060

10 UK Parliament. Engagements. Volume 705: debated on Wednesday 8 December 2021. 2021. https://hansard.parliament.uk/commons/2021-12-08/debates/DB36FDA8-C784-4AEE-8D0CF95FBB5345E9/Engagements

11 Allegretti A, Walker P. Covid parties review to look at event PM said to have attended. 2021. https://www.theguardian.com/world/2021/dec/09/review-widens-into-covid-restriction-floutinggovernment-parties

12 Cabinet Office. Contingency Planning. 2021. https://www.gov.uk/government/publications/covid19-response-autumn-and-winter-plan-2021/covid-19-response-autumn-and-winter-plan2021\#contingency-planning

13 Fancourt D, Steptoe A, Wright L. The Cummings effect: politics, trust, and behaviours during the COVID-19 pandemic. Lancet 2020;396:464-5.

doi: 10.1016/S0140-6736(20)31690-1. pmid: 32771083

14 Cowper A. Cowper's Cut: Character and chronology, Cummings and goings. 2020 https://www.hsj.co.uk/policy-and-regulation/cowpers-cut-character-and-chronology-cummingsand-goings/7027708.article

15 Jackson J, Bradford B, Yesberg J, et al. Public compliance and COVID-19: Did Cummings damage the fight against the virus, or become a useful anti-role model? 2020. https://blogs.lse.ac.uk/politicsandpolicy/public-compliance-covid19-june/

16 Ford M. Tribute for NHS staff who have died from Covid-19 while 'battling for others'. 2021. https://www.nursingtimes.net/news/coronavirus/tribute-for-nhs-staff-who-have-died-from-covid19-while-battling-for-others-05-07-2021/ 